ACTA MYCOLOGICA

Vol. 41 (1): 95-98

2006
Dedicated to Professor Alina Skirgietto

on the occasion of her ninety fifth birthday

\title{
Three rare lignicolous fungi from Sicily (S Italy)
}

\author{
GIUSEPPE VENTURELLA ${ }^{1}$, ANNAROSA BERNICCHIA ${ }^{2}$ and ALESSANDRO SAITTA ${ }^{1}$
}

\author{
${ }^{1}$ Department of Botany, University of Palermo \\ Via Archirafi 38, I 90123 Palermo, gvent@unipa.it \\ ${ }^{2}$ Dipartimento di Scienze e Tecnologie Agroambientali, Università di Bologna \\ Viale Fanin 44, I 40127 Bologna, abernicc@agrsci.unibo.it
}

Venturella G., Bernicchia A., Saitta A.: Three rare lignicolous fungi from Sicily (S Italy). Acta Mycol. 41 (1): 95 98, 2006.

Sarcodontia crocea (Schwein.) Kotl., Oligoporus mappa (Overh. \& Lowe) Gilbn. \& Ryvarden and Inonotus rickii (Pat.) D.A. Reid. are reported for the first time from Sicily (southern Italy). Ecological and distributive features on the three relevant species are also here provided.

Key words: lignicolous fungi, ecology, distribution, Sicily, Mediterranean area

\section{INTRODUCTION}

The increase of mycological investigation in Sicily permitted to select a huge number of fungi, to publish lists and maps of distribution, to collect many ecological data and to evaluate the rareness of some taxa. A specific field of investigation was devoted to lignicolous fungi which are widely distributed in Sicily on different plants of agronomic, forestry and ornamental interest.

A list of lignicolous species, host plants and substrata, referred to 209 taxa, was recently published by Saitta et al. (2004). Besides distributive and ecological data on eleven Aphyllophorales were reported by Venturella et al. (in press).

In this paper the results of field investigation on three lignicolous fungi, considered as rare and/or infrequent in Italy, are pointed out.

\section{MATERIALS AND METHODS}

In the framework of a project for the assessment of fungal biodiversity in Sicily, observations on lignicolous fungi were carried out in different forest ecosystems, parks and botanical gardens.

The basidiomata were collected with a knife, preserved in a paper bag, and identified in laboratory, after rehydratation in $\mathrm{KOH}$, using a Leica microscopy. The monographies of Bernicchia (2005); Eriksson et al. (1981) and Hjortstam et 
al. (1987) were consulted for identification and nomenclatural notes. The herbarium samples were prepared in a dryer and kept in the Herbarium Mediterraneum (PAL).

The distributive data were referred to the grid map 1:50,000 of the Official Map of the Italian State (I.G.M.I.), following the methodology proposed by Padovan (1994) for the checklist of macromycetes in Italy. In particular the sheets number 595 (Palermo), 609 (Termini Imerese) and 620 (Lercara Friddi) were divided into 64 subunits. Consequently, a number composed by six figures were attributed to each recorded taxon.

\section{RESULTS}

\section{Sarcodontia crocea (Schwein.) Kotl.}

Specimen examined. Sicily (S Italy). Piano Torre (province of Palermo), $950 \mathrm{~m}$, Quercus ilex L. wood, on stumps of Q. ilex, 01 October 2005, 609122, leg. A. Saitta (Fig. 1a, b).

Comments. This species was gathered on stumps in a $Q$. ilex wood located within the Madonie Park, a protected area in the province of Palermo (N Sicily). In the locality of collection the forest management, carried out by the Forestry Administration, lead to accumulation of a huge amount of logs, branches, stumps and rotten woods which are easily overrun with rot decay fungi. $S$. crocea, previously listed in Italy from Emilia Romagna, Friuli Venezia Giulia and Lombardia and collected on old apple-trees only, is reported for the first time from Sicily. This new finding extend southwards the area of distribution of $S$. crocea and confirm the presence of such species on different broad-leaved host plants. It is also interesting to be note that $S$. crocea is known from Finland, Sweden, Denmark, Poland, Germany, The Netherlands and U.K., but it is considered threatened in all these countries. In Estonia it is listed as extinct (Læss $\emptyset$ e 2004). The rarity of $S$. crocea is probably caused by the progressive abandonment of tilled fields and the decrease in the number of old apple-trees.

\section{Oligoporus mappa (Overh. \& Lowe) Gilbn. \& Ryvarden}

Specimen examined. Sicily (S Italy). Monte Rose (province of Palermo), $1000 \mathrm{~m}$, mixed reafforestation of Pinus halepensis Miller and Cupressus sempervirens L., on trunks of C. sempervirens, 26 September 2004, 620313, leg. C. Vasile (Fig. 2a, b).

Comments. O. mappa grows as saprotroph on conifer woods, rarely on broad-leaved plants, and sometimes on manufactured wood. The only report of such species for Italy arise from Bernicchia (1990) and is referred to a collection on Juniperus phoenicea L. in Foresta Montes (Supramonte di Orgosolo) in the province of Nuoro (Sardegna). O. mappa was recently recorded in Sicily, in a mixed reafforestation of $P$. halepensis and $C$. sempervirens, on fallen trunks of $C$. sempervirens. It is also interesting to note that the new locality here reported is located at the same altitude, i.e. 1000 $\mathrm{m}$, of the previous locality pointed out by Bernicchia (1990). O. mappa is a very rare species in Europe but widely distributed. 


\section{Inonotus rickii (Pat.) D.A. Reid}

Specimen examined. Sicily (S Italy). Botanical garden (town of Palermo), $3 \mathrm{~m}$, on stumps of Acer negundo L., 23 October 2003, 595433, leg. C. Comparetto (Fig. 3a, b). Comments. The first finding for Europe was reported by Jaque noud (1985) as anamorph state on Parkinsonia aculeata L. in Villa Giulia, a public garden of the town of Palermo (Sicily). A second collection, on Schinus molle L., from Sicily was published by Intini (1988) Recently, Intini (2002) gathered I. rickii on Acer negundo L. in tree plantations along the streets of Sevilla (Spain). I. rickii was also found by Annesi et al. (2003) on A. negundo and Celtis australis L. in Rome and by Saitta et al. (2005) on $A$. negundo in Villa Giulia (Palermo). Typical brown, powdery masses of chlamydospores of $I$. rickii were observed near wounds or pruning cuts on Quercus cerris L. in the Botanical Garden of Palermo and on Sambucus nigra L. and Aberia caffra Hook. F. \& Harv. in Catania (Annesi et al. 2005). I. rickii is also reported from Montenegro, Greece and France (Bernicchia 2005) and Morocco (Bernicchia, in litteris).

\section{CONCLUSIONS}

The distribution of lignicolous fungi in Italy is still not well known and the availability of maps mainly depends on the presence of mycologists in the different regions of the country.

The application of the term "rare" in mycology is not suitable for fungi recorded only one time or in absence of long term researches but, in some cases, the results of field investigation, the availability of ecological and literature data allowed to evaluate the rareness of species belonging to taxonomic group not well investigated. This is the very case of Sarcodontia crocea, Oligoporus mappa and Inonotus rickii which are recognized as rare or threatened at European level.

The progressive abandonment of tilled fields, the decrease in the number of old cultivars and the disappearance of specific host plants are the main factors responsible of decline in lignocolous species together with unsuitable forest managements particularly in protected areas.

The finding of S. crocea, O. mappa and I. rickii contributed to widen the area of distribution in Europe and to provide additional ecological data.

Acknowledgements. The authors wish to thank Dr David Minter for kindly revised this manu script.

\section{REFERENCES}

Annesi T., Coppola R., Motta E. 2003. Decay and canker caused by Inonotus rickii spreading on more urban tree species. For. Path. 33: 405412.

Annesi T., Coppola R., D'Amico L., Motta E. 2005. First report of Aberia caffra and Quercus cerris as hosts of Inonotus rickii. Plant. Dis. 89: 107.

Bernicchia A. 1990. Polyporaceae s.l. in Italia. Istituto di Patologia Vegetale, Università degli Studi di Bologna.

Bernicchia A. 2005. Polyporaceae s.1. Fungi Europaei, 10. Ed. Candusso, Savona (italia).

Eriksson J., Hjortsta m K., Ryvarden L. 1981. The Corticiaceae of North Europe. Vol. 6. Phlebia Sarcodontia. Fungiflora, Oslo, Norway. 
G. Venturella et al.

Hjortsta m K., Larsson K.H., Ryvarden L. 1987. The Corticiaceae of North Europe. Introduction and keys. Vol. 1. Fungiflora, Oslo, Norway.

Intini M.G. 1988. Contributo alla conoscenza dei funghi lignicoli Italiani: Inonotus rickii (Pat.) Reid. Micol. Ital. 17 (1): 4953.

Intini M.G. 2002. First report of Inonotus rickii causing canker rot on boxelder in Europe. Plant Dis. 86: 922.

J a qu e n o u d M.1985. Inonotus rickii, un polypore nouveau pour la flore européenne. Mycologia Hel vetica I (6): 371391.

Læss øe T. 2004. Æblepig (Sarcodontia crocea) nu fundet i Danmark. I: Vesterholt, J. Usædvanlige danske svampefund. Svampe 49: 4042.

Padovan F.1994. Mappatura dei macromiceti in Italia (problemi cartografici). Rivista di Micologia 37 (1): 5969.

Ryvarde n L., Gilberts on R. L. 1993. European Polypores. Fungiflora, Oslo (Norway).

Saitta A., Bernicchia A., Venturella G. 2004. Contributo alla conoscenza dei funghi lignicoli della Sicilia. Inform. Bot. Ital. 36 (1): 192202.

Saitta A., Pecorella E., Comparetto C. 2005. 9 Inonotus rickii (Pat.) D. A. Reid. P. 191. (In:) Venturella G., Raimondo F. M. (eds). I funghi cariogeni delle alberature di parchi, giardini e strade 1 18. Quad. Bot. Ambientale Appl. 15(2004): 181201.

Venturella G., Bernicchia A., Saitt a A. Contribution to the knowledge of diversity and distribu tion of lignicolous fungi from Sicily (southern Italy). Bocconea (in press).

\section{Trzy rzadkie gatunki grzybów nadrzewnych z Sycylii}

\section{Streszczenie}

Autorzy podają trzy nowe dla Sycylii gatunki grzybów: Sarcodontia crocea, Oligoporus mappa i Inonotus rickii. Dla każdego gatunku podana jest chrakterystyka ekologiczna, barwna fotografia i mapa rozmieszczenia na terenie Włoch. 